\title{
China and the UnCLOS: Practices and Policies
}

\author{
Xinmin Ma \\ Ambassador of China to Sudan; Former Deputy Director-General, \\ Department of Treaty and Law, Ministry of Foreign Affairs of China, \\ Beijing, China \\ ma_xinmin@mfa.gov.cn
}

\begin{abstract}
The 1982 United Nations Convention on the Law of the Sea (UNCLOS or the Convention) is one of the most important accomplishments in the development of international law in the twentieth century. As a comprehensive compilation of the modern law of the sea, the UNCLOS not only codifies numerous customary rules of law of the sea, but also progressively develops the treaty rules of law of the sea. Especially the three bodies established by the UNCLOS, namely the International Seabed Authority (ISA), the International Tribunal for the Law of the Sea (ITLOS) and the Commission on the Limits of the Continental Shelf (CLCS), have played an important role in facilitating the implementation of the UNCLOS and promoting stability and development of the international marine order. As a member of the big family of the States Parties to the UNCLOS, China has been faithfully fulfilling the obligations of the UNCLOS, fully engaged in the work of the three bodies and actively contributing its solutions and wisdom. In the process of implementing the UNCLOS, China has formed its own practices and policies.
\end{abstract}

\section{Keywords}

UNCLOS - China - practice - policy 
The UNCLOS establishes a new international marine legal order and provides a basic legal framework for human's peaceful uses of marine space and conducting maritime activities. China has participated in the whole process of UNCLOS negotiations, fully and faithfully implemented the UNCLOS, actively taken part in the global ocean governance, and thus made significant contributions to maintaining the fair and reasonable international marine order. It is primarily manifested in three aspects.

\subsection{China Has Actively Participated in the Maritime Legislation}

The negotiation on the UNCLOS is the first multilateral legislation activity that China has taken part in after the restoration of its lawful seat in the United Nations. In 1971, China restored its lawful seat in the United Nations, and on December 21 in the same year, the General Assembly adopted a resolution to include China as a member of the United Nations Seabed Committee. Since 1973, China has participated in the whole process of the Third United Nations Conference on the Law of the Sea. China supports most developing countries in their efforts to establish a fair and reasonable marine order, as well as coastal States in expanding their maritime entitlements and jurisdiction, which significantly contributes to the conclusion of the UNCLOS. China was among the first group of 119 countries that signed the Convention, and it ratified the Convention on 15 May $1996 .^{2}$ After the adoption of the UnClos, China has participated in formulating the 1994 Agreement relating to the Implementation of Part XI of the UNCLOS (Implementing Agreement) and the 1995 Agreement relating to the Conservation and Management of Straddling Fish Stocks and Highly Migratory Fish Stocks (UNFSA). With respect to the former, China supports that exploration and exploitation of the resources of the Area should be market oriented, and the exploitation shall take place in accordance with sound commercial principles. With respect to the latter, China supports enhancing conservation and sustainable use of fishery resources in the high seas through regional and subregional arrangements. China has also actively involved in the formulation of three regulations on resource exploration in the Area, namely the 2000 Regulations on Prospecting and Exploration for Polymetallic Nodules in

1 This article was the address made by the author at the Sixth International Symposium on Scientific and Legal Aspects of the Regimes of the Continental Shelf and the Area held in China on May 30, 2018. The article represents only the views of the author.

2 Available at http://www.npc.gov.cn/wxzl/gongbao/20oo-12/16/content_5003571.htm, last visited on December 9, 2018. 
the Area, the 2010 Regulations on Prospecting and Exploration for Polymetallic Sulphides in the Area and the 2012 Regulations on Prospecting and Exploration for Cobalt-Rich Ferromanganese Crusts in the Area, so as to effectively implement the provisions that the Area and its resources are the common heritage of mankind in the UNCLOS and the 1994 Implementing Agreement.

At present, the ongoing negotiations on the Conservation and Sustainable Use of Marine Biological Diversity of Areas Beyond National Jurisdiction (BBNJ) international instrument and the Exploitation Regulations of the Deep-sea Mineral Resources (Exploitation Regulations) signify two latest legislative processes in implementing the UNCLOS. The Chinese government has made written submissions twice respectively on the two instruments in progress ${ }^{3}$ and will continuously be engaged in the relevant processes in a constructive manner, so as to offer China's wisdom and solutions.

Meanwhile, China is an active participant in formulating international treaties concerning shipping safety and security, and prevention of vesselinduced pollution under the framework of International Maritime Organization (IMO), including the 1996 Protocol to the Convention on the Prevention of Marine Pollution by Dumping of Wastes and Other Matter, and the 1992 Protocol to the International Convention on Civil Liability for Oil Pollution Damage. ${ }^{4}$ China also takes part in formulating relevant international legal instruments concerning the conservation and management of fishery resources under the Food and Agriculture Organization (FAO) framework, including the 1993 Agreement to Promote Compliance with International Conservation and Management Measures by Fishing Vessels on the High Seas, the 1995 Code of Conduct for Responsible Fisheries, the 2001 International Plan of Action to Prevent, Deter

3 Written Submission of the Chinese Government on Elements of a Draft Text of an International Legally Binding Instrument under the United Nations Convention on the Law of the Sea on the Conservation and Sustainable Use of Marine Biological Diversity of Areas Beyond National Jurisdiction (March 7, 2017), available at http://www.un.org/depts/los/biodiversity/ prepcom_files/rolling_comp/China.pdf, last visited on December 9, 2018; Written Submission of the Government of the People's Republic of China on Elements of a Draft Text of an International Legally Binding Instrument under the United Nations Convention on the Law of the Sea on the Conservation and Sustainable Use of Marine Biological Diversity of Areas Beyond National Jurisdiction (As revised on April 20, 2017), available at http://www.un.org/ depts/los/biodiversity/prepcom_files/streamlined/China.pdf, last visited on December 9, 2018; Comments by the Government of the People's Republic of China on the Draft Regulations on Exploitation of Mineral Resources in the Area (20 December 2017), available at http://www.isa.org.jm/files/documents/EN/Regs/2017/List-1.pdf, last visited on December 9, 2018.

4 Md. S. Karim, Prevention of Pollution of the Marine Environment from Vessels, Springer International Publishing Switzerland, 2015, pp. 15-41. Available at http://www.fmprc.gov.cn/ web/ziliao_674904/tytj_674911/tyfg_674913/t4985.shtml, last visited on December 9, 2018. 
and Eliminate Illegal, Unreported and Unregulated Fishing, and the 2009 Agreement on Port State Measures to Prevent, Deter and Eliminate Illegal, Unreported and Unregulated Fishing. ${ }^{5}$ At the same time, China actively participates in the establishment of regional fisheries management mechanisms, and has joined six Regional Fisheries Management Organizations, namely International Commission for the Conservation of Atlantic Tunas, Indian Ocean Tuna Commission, Inter-American Tropical Tuna Commission, Western and Central Pacific Fisheries Commission, South Pacific Regional Fisheries Management Organization, and North Pacific Fisheries Commission. ${ }^{6}$ China also helps these organizations in formulating fisheries resource conservation and management measures, and promotes the conservation, management and sustainable use of fisheries resources.

\subsection{China Has Fully Engaged in the UNCLOs Implementation}

In this respect, China's work mainly covers five aspects.

1.2.1

China Has Taken Measures to Keep Its Domestic Legislation

In Line with the UNCLOS

China has made considerable efforts in improving its domestic ocean laws and regulations based on the UNCLOS. As for the establishment of its maritime space regulations, China successively enacted the Law on the Territorial Sea and the Contiguous Zone in $1992^{7}$ and the Law on the Exclusive Economic Zone and the Continental Shelf in $1998 .^{8}$ China published most parts of the territorial baselines of land territory and the baselines of Xi'sha Islands in 1996, ${ }^{9}$ as well as the baselines of the Diaoyu Dao and its affiliated islands later in 2012. ${ }^{10}$ With respect to the coastal States' right to exercise control over its contiguous zone, during the negotiation of the UNCLOS, thirty countries, including China, proposed to include "security" as another justification to exercise control in addition to customs, finance, immigration and sanitation

$5 \quad$ Available at http://www.fao.org/china/en/, last visited on December 9, 2018.

6 Available at https://www.iccat.int/Documents/BienRep/REP_EN_O2-O3_II_2.pdf, http:// www.iotc.org/, https://www.iattc.org/HomeENG.htm, https://www.wcpfc.int/, https:// www.sprfmo.int/, https://www.npfc.int/, last visited on December 9, 2018.

7 Available at http://www.npc.gov.cn/englishnpc/Law/2007-12/12/content_1383846.htm, last visited on December 9, 2018.

8 Available at http://www.npc.gov.cn/englishnpc/Law/2007-12/11/content_1383573.htm, last visited on December 9, 2018.

9 Available at http://www.un.org/Depts/los/LEGISLATIONANDTREATIES/PDFFILES/ CHN_1996_Declaration.pdf, last visited on December 9, 2018.

10 Available at http://www.fmprc.gov.cn/mfa_eng/topics_665678/diaodao_665718/tg68769 .shtml, last visited on December 9, 2018. 
reasons. The compromised result was that, the Convention should not contain any explicit rule in this regard, but implied recognition should be given to States' reasonable security concerns. Therefore, the inclusion of the right to control over security issues in its contiguous zone in the China's 1992 Law on the Territorial Sea and the Contiguous Zone is in accordance with the spirit of the UNCLOS. ${ }^{11}$ With respect to the innocent passage by foreign warships in the territorial sea, the Convention does not contain explicit rules. But it allows States to adopt laws and regulations relating to innocent passage. In accordance with the UNCLOS and by referring to relevant State practices, China prescribes in its Law on the Territorial Sea and the Contiguous Zone that, foreign ships for military purposes shall be subject to approval by the Chinese government for entering the territorial sea of China. ${ }^{12}$ On regulating the maritime activities, in order to exercise rights and perform duties in accordance with the UNCLOS, China has also enacted or revised a series of laws and regulations in the fields of marine environmental protection, marine scientific research, shipping, fisheries, deep sea resources, navigation safety and so on, including the 2016 Law on the Exploration and Development of Resources in Deep Seabed Areas, ${ }^{13}$ the 1996 Provisions on Administration of Foreign-Related Marine Scientific Research, ${ }^{14}$ the 1982 Marine Environment Protection Law (amended in 1999, 2013, 2016 and 2017), ${ }^{15}$ the 1986 Fisheries Law (amended in 2000, 2004, 2009 and $2013)^{16}$ and the 1983 Maritime Traffic Safety Law (amended in 2016). ${ }^{17}$

\section{China's Support to the Work of Three Implementing}

Bodies of the UNCLOS

China appreciates the role of the ITLOS in peaceful settlement of maritime disputes. We have made financial assistance to capacity building programs of the Tribunal. Three respected Judges from China, Professor Zhao Lihai, Mr. Xu Guangjan and Dr. Gao Zhiguo have made significant contributions to the interpretation and application of the UNCLOS.

\footnotetext{
11 The United Nations Convention on the Law of the Sea (UnCLOS), Article 21.

12 Law on the Territorial Sea and the Contiguous Zone, 1992, Article 6.

13 Available at http://en.pkulaw.cn/display.aspx?cgid=264866\&lib=law, last visited on December 9, 2018.

14 Available at http://www.lawinfochina.com/display.aspx?lib=law\&id=12053\&CGid=, last visited on December 9, 2018.

15 Available at http://www.china.org.cn/english/environment/34356.htm, last visited on December 9, 2018.

16 Available at http://www.china.org.cn/china/LegislationsForm2001-2010/2011-02/14/ content_21917138.htm, last visited on December 9, 2018.

17 Available at http://www.npc.gov.cn/englishnpc/Law/2007-12/13/content_1383972.htm, last visited on December 9, 2018.
} 
In terms of the CLCS, I am honored to say, like Professor Park, Mr. Awosika and Mr. Galo, Chinese leading expert Professor Lyu Wenzheng has been serving as a member of the CLCS over the past 20 years since establishment of the Commission and has made great contributions to the work of the Commission. China has donated annually to the voluntary trust fund of the Commission to assist the participation of the members from developing States. China has attached great importance to the delimitation of outer continental shelf beyond 200 nautical miles, and made the submission to the Commission concerning part of the East China Sea in 2012. ${ }^{18}$ With respect to Japan's claim over the continental shelf and outer continental shelf measured from the basepoint Oki-no-Tori Shima in its 2008 Submission to the CLCS, China has presented note verbales to the Secretary-General of the UN for many times, pointing out that the so-called Oki-no-Tori Shima, on its natural conditions, is "rock" as provided in Article 121 (3) of the UNCLOS, and shall have no exclusive economic zone or continental shelf. Japan's claim of the continental shelf based on the rock of Oki-no-Tori breaches international law, encroaches upon the Area and impairs the overall interests of the international community. ${ }^{19}$

China is an active participant and builder in the international seabed affairs. As a longtime member of Group A of the Council of the ISA, China has sponsored totally four exploration contracts granted to the China Ocean Mineral Resources R\&D Association and China Minmetal Corporation respectively. As a State sponsoring the exploration contracts, China looks forward to early realization of the exploitation of the deep-sea mineral resources, and transformation from words into reality of the principle of common heritage of mankind as early as possible. Amid new situations, China will stay committed to the rulemaking process of the ISA, including the formulation of strategic plan and regional environment management plans.

1.2 .3

China's Involvement in Relevant Mechanisms under the UNCLOS or the UN Framework

These mechanisms include the Meeting of the States Parties to the UnClos, the consideration of the General Assembly on the Item "oceans and law of the sea", the Consultation on the Ominous Resolution on the Oceans and Law of the sea, the Sustainable Fisheries Resolution Consultation, the UN Informal

18 Available at http://www.un.org/Depts/los/clcs_new/submissions_files/submission_chn_ 63_2012.htm, last visited on December 9, 2018.

19 Available athttp://www.un.org/depts/los/clcs_new/submissions_files/jpno8/chn_zaug11_ e.pdf, last visited on December 9, 2018. 
Consultation Process on the Oceans and the Law of the Sea, as well as the Regular Process on the Global Environment Reporting and Assessment.

1.2 .4

China's Engagement in the International Maritime

Law-Enforcement Cooperation

China makes great contributions to addressing non-traditional security challenges such as piracy, armed robbery, and unlawful acts against the maritime security.

In combating Somali piracy, China has fully participated in the consultation and implementation of relevant resolutions of the UN Security Council and has been continuously sending naval fleets to carry out escort missions in the Gulf of Aden and Somalian waters. By July 2017, 26 fleets had been sent by the Chinese Navy to escort more than 6400 Chinese and foreign ships, about 3000 suspected pirate vessels had been driven away, and security had been guaranteed for major international trade routes. ${ }^{20}$

China has ratified the 1988 Convention for the Suppression of Unlawful Acts against the Safety of maritime Navigation and the 1988 Protocol for the Suppression of Unlawful Acts against the Safety of Fixed Platforms Located on the Continental Shelf, and has punished unlawful acts against maritime safety in accordance with these laws. ${ }^{21}$

China also pays high attention to the threat to international peace and security by the proliferation of Weapons of Mass Destruction (WMD). We uphold the enhancement of international cooperation on non-proliferation based on the UN Charter and the Treaty on the Non-Proliferation of Nuclear Weapons, in order to safeguard both global and regional peace and stability.

1.2.5 China is Involved in Constructive Judicial Practices under the UNCLOS System

With respect to the South China Sea Arbitration unilaterally initiated by the Philippines, China did not accept or participate in the arbitration so as to safeguard its own lawful rights and interests, as well as the authority and integrity of the UnClos. Nor did China accept or recognize the Tribunal's Awards. In addition to a series of declarations, the Position Paper of the Government of the People's Republic of China on the Matter of Jurisdiction in the South China Sea Arbitration Initiated by the Republic of the Philippines was issued on December 7 ,

20 Available at http://www.fmprc.gov.cn/mfa_eng/xwfw_665399/s2510_665401/t1505355 .shtml, last visited on December 9, 2018.

21 Available at https://treaties.un.org/pages/showDetails.aspx?objid=080000028oobgbd 7 , last visited on December 9, 2018. 
2014 (Position Paper). ${ }^{22}$ The Position Paper elaborates China's position that the Tribunal does not have jurisdiction and its corresponding reasoning. It also clarifies that China's position of non-acceptance and non-participation has sufficient legal basis in international law. The Chinese Society of International Law also published two critical study reports on the Tribunal's awards, namely the Tribunal's Award in the "South China Sea Arbitration" Initiated by the Philippines Is Null and Void ${ }^{23}$ in June 2016, and the South China Sea Arbitration Awards: A Critical Study 24 in May 2018.

With respect to the two requests to the ITLOS or its Seabed Disputes Chamber to render Advisory Opinions, i.e. one on responsibilities and obligations of sponsoring States, and the other submitted by Sub Regional Fisheries Commission (SRFC), China has respectively submitted written statements to clarify its positions. In the 2010 Advisory Opinion on Responsibilities and Obligations of Sponsoring Sates with respect to Activities in the Area, the Chinese government submits in its written statement that, the responsibilities and obligations of a sponsoring State under the Convention and the 1994 Agreement shall be reasonable and appropriate, under which the sponsoring State may exercise supervision over the contractor without shouldering undue burdens. The written statement stresses that the obligation of securing compliance is an obligation of "due diligence" and an obligation of conduct, instead of an obligation of result. If a sponsoring State has taken all necessary and appropriate measures in accordance with legal requirements, it shall not be liable for any damage caused by non-compliance with its obligations on part of a sponsored Contractor. ${ }^{25}$ In the 2013 Request for an Advisory Opinion Submitted by the SRFC, the Chinese government submits in its written statement that, the UNCLOS and the Statute of the ITLOS do not contain any explicit provision on

22 Position Paper of the Government of the People's Republic of China on the Matter of Jurisdiction in the South China Sea Arbitration Initiated by the Republic of the Philippines ("Position Paper"), 7 December 2014, Available at http://www.fmprc.gov.cn/nanhai/ eng/snhwtlcwj_1/t1368895.htm, last visited on December 9, 2018.

23 Chinese Society of International Law, the Tribunal's Award in the "South China Sea Arbitration" Initiated by the Philippines Is Null and Void, Law Press, 2016. Available at http:// www.csil.cn/News/Detail.aspx?AId=201, last visited on December 9, 2018.

24 Chinese Society of International Law, the South China Sea Arbitration Awards: A Critical Study, Foreign Languages Press, 2018. See also Special Issue, Chinese Journal of International Law, Oxford University Press, Vol. 17, No. 2, June 2018.

25 Written Statement of the People's Republic of China, Responsibilities and obligations of States sponsoring persons and entities with respect to activities in the Area (Request for Advisory Opinion submitted to the Seabed Disputes Chamber), available at https://www .itlos.org/fileadmin/itlos/documents/cases/case_no_17/Statement_China.pdf, last visited on December 9, 2018. 
the advisory competence of the full bench of the ITLOS. Without an express authorization, there is evidently no legal basis for the full bench of the Tribunal to exercise advisory jurisdiction and the request should be declined. ${ }^{26}$

\subsection{China Has Deeply Participated in Global Governance of the Oceans and Seas}

As a responsible major country, China attaches great importance to establishing and improving the international ocean governance. Apart from being involved in relevant mechanisms under the UNCLOS, China has proposed the "21st Century Maritime Silk Road" Initiative, which calls for maritime cooperation among States based on the principles of consultation, contribution and shared benefits in order to jointly cope with risks and challenges. To implement Goal 14 of the 2030 Agenda for Sustainable Development (SDG 14), the Chinese government released its National Plan on Implementation of the Agenda in September $2016,{ }^{27}$ which connects SDG 14 with its domestic maritime development agenda. In its 13th Five-Year Plan for the National Economic and Social Development adopted in the same year, China specified the 2030 Agenda for Sustainable Development, including turning SDG 14 into missions such as marine economy, environmental protection, disaster prevention and reduction, scientific and technological innovation, and international cooperation.

Furthermore, China has advocated international cooperation and achieved fruitful outcomes in fields of international shipping, marine scientific research, marine environmental protection, and maritime safety and security. We have carried out communication and cooperation programs with more than 50 countries on blue economy, marine environmental protection, disaster prevention and reduction, and combating climate change. We have signed more than 30 bilateral agreements in this regard. Meanwhile, we help to construct headquarters or branches in China for 8 international maritime organizations, set up the Chinese Government Maritime Scholarship and a variety of training programs, and cultivate thousands of maritime professionals for developing countries annually.

Based on its own development experience, China will proactively establish blue partnerships in maritime field with various states and international

26 Written Statement of the People's Republic of China, Request for an advisory opinion submitted by the Sub-Regional Fisheries Commission (SRFC), available at https://www .itlos.org/fileadmin/itlos/documents/cases/case_no.21/written_statements_round1/ C21_8_China_orig_Eng.pdf, last visited on December 9, 2018.

27 China's National Plan on Implementation of the 2030 Agenda for Sustainable Development, available at http://www.fmprc.gov.cn/web/zyxw/Wo20161012709956373709.pdf, last visited on December 9, 2018. 
organizations featuring openness and inclusiveness, pragmatic concreteness, as well as mutual benefits and win-win results. In addition, China is willing to share the responsibility of global ocean governance with all parties to enhance cooperative research and survey on and to tackle non-traditional security threats such as sea-level rise, coast erosion, marine debris and micro-plastics, ocean acidification and maritime crimes, etc. China will work together with other countries to create harmonious, beautiful and secure marine environment, in efforts to make great contributions to the sustainable development of the oceans and seas.

Based on full implementation of the UNCLOS in good faith and through longterm practices, China has gradually established its basic policies and positions on the law of the sea mainly in the following eight aspects.

\subsection{Legal Basis}

China insists that the UNCLOS and general international law are in parallel. Just like both wings of a bird, neither can be neglected. The UNCLOS has established a basic legal framework for the modern law of the sea regime. But it is far from covering all matters concerning maritime rights and obligations. With respect to the matters not regulated by the UNCLOS, general international law will continue to play its due role. The typical examples include historic rights and the regime of outlying archipelagos of a continental State. ${ }^{28}$

With respect to historic rights, the Law on the Exclusive Economic Zone (EEZ) and the Continental Shelf enacted by China in 1998 establishes the legal regime of China's EEZ and the continental shelf, in which Article 14 expressly stipulates that, the provisions in this law shall not affect the historic rights that the People's Republic of China enjoys. ${ }^{29}$ Pursuant to this, China's rights to the EEZ and continental shelf of its "Four Sha" Islands do not prejudice the continuing viability of historic rights that China enjoys under customary international law. China's historic rights and entitlements to EEz and continental

28 Position Paper of the Government of the People's Republic of China on the Matter of Jurisdiction in the South China Sea Arbitration Initiated by the Republic of the Philippines, 7 December, 2014, available at http://www.fmprc.gov.cn/nanhai/eng/snhwtlcwj_1/ t1368895.htm, last visited on December 9, 2018.

29 Law on the Exclusive Economic Zone and the Continental Shelf of the People's Republic of China, Article 14, available at http://www.npc.gov.cn/englishnpc/Law/2007-12/11/ content_1383573.htm, last visited on December 9, 2018. 
shelf can co-exist. According to the Statement of the Government of the People's Republic of China on China's Territorial Sovereignty and Maritime Rights and Interests in the South China Sea of 12 July 2016, China's territorial sovereignty and maritime rights and interests in the South China Sea include not only the territorial sovereignty over Nanhai Zhudao, as well as internal waters, territorial sea, contiguous zone, exclusive economic zone and continental shelf as those provided in the UNCLOS, but also historic rights in accordance with general international law. ${ }^{30}$

\section{2 $\quad$ The Regime of Maritime Features}

Apart from recognizing the legal status of archipelagic States, islands, rocks, low-tide elevations, submarine features, artificial islands, installations and structures, China also insists that the regime of continental States' outlying archipelagos exists in general international law. China considers that this regime is the matter not regulated by the UNCLOS as indicated in its Preamble, and should be governed by the rules and principles of general international law. ${ }^{31}$ China constantly claims that Dongsha Islands, Xisha Islands, Zhongsha Islands and Nansha Islands are China's outlying archipelagos. Various islands, rocks, low-tide elevations, "interconnecting waters" and "other natural features" in each archipelago constitute its integral parts. China consistently maintains territorial sovereignty and maritime entitlements based on each Islands as a unit. The legal status of each archipelago and its maritime entitlements should be considered in perspective of the Islands as a whole, rather than in view of its constituting part - the individual island, rock and low-tide elevation. The Declaration of the People's Republic of China on the Territorial Sea in 1958 affirms that China's land territory includes the Dongsha Islands, the Xisha Islands, the Zhongsha Islands and the Nansha Islands, and that the rule of 12 nautical miles of the territorial Sea applies to the above-mentioned Islands. ${ }^{32}$ Article 2 of China's Law on Territorial Sea and the Contiguous Zone in 1992 stipulates that, "[t]he land territory of the People's Republic of China includes ... the Dongsha Islands, the Xisha Islands, the Zhongsha Islands and the Nansha Islands, as well as all the other islands belonging to the People's

30 Statement of the Government of the People's Republic of China on China's Territorial Sovereignty and Maritime Rights and Interests in the South China Sea, available at http:// www.fmprc.gov.cn/nanhai/eng/snhwtlcwj_1/t1379493.htm, last visited on December 9, 2018.

31 The unclos, Preamble.

32 Available at http://www.gov.cn/test/20o6-o2/28/content_213287.htm, last visited on December 9, 2018. 
Republic of China." ${ }^{33}$ The decision of the Standing Committee of the National People's Congress on the ratification of the UNCLOS in 1996 reaffirms China's sovereignty over the above-mentioned islands. In its Note Verbale of 14 April 2011 addressed to Secretary-General of the United Nations, the Permanent Mission of China to the United Nations states that "under the relevant provisions of the 1982 United Nations Convention on the Law of the Sea, as well as the Law of the People's Republic of China on the Territorial Sea and the Contiguous Zone (1992) and the Law on the Exclusive Economic Zone and the Continental Shelf of the People's Republic of China (1998), China's Nansha Islands is fully entitled to Territorial Sea, Exclusive Economic Zone (EEZ) and Continental Shelf." ${ }^{34}$ The Position Paper of the Government of the People's Republic of China on the Matter of Jurisdiction in the South China Sea Arbitration Initiated by the Republic of the Philippines of 7 December 2014 explicitly indicates that, "[t]he Nansha Islands comprises many maritime features. China has always enjoyed sovereignty over the Nansha Islands in its entirety, not just over some features thereof". 35 "[I]n order to determine China's maritime entitlements based on the Nansha Islands under the Convention, all maritime features comprising the Nansha Islands must be taken into account."36 In this regard, the Statement of the Government of the People's Republic of China on China's Territorial Sovereignty and Maritime Rights and Interests in the South China Sea of 12 July 2016 expressly points out that, China has sovereignty over Nanhai Zhudao, consisting of Dongsha Qundao, Xisha Qundao, Zhongsha Qundao and Nansha Qundao; China has internal waters, territorial sea, contiguous zone, exclusive economic zone and continental shelf, based on Nanhai Zhudao. ${ }^{37}$

\subsection{Maritime Space}

On the one hand, according to the UnCLOS and China's domestic laws, the marine areas within China's jurisdiction not only include those over which China is entitled to exercise jurisdiction under the UNCLOS, namely the internal waters, territorial seas, contiguous zones, exclusive economic zones

33 Law of the People's Republic of China on the Territorial Sea and the Contiguous Zone, Article 2.

34 Available at http://www.un.org/depts/los/clcs_new/submissions_files/mysvnm33_og/ chn_2011_re_phl_e.pdf, last visited on December 9, 2018; See also Position Paper, para. 21. Position Paper, para. 20.

36 Position Paper, para. 21.

37 Statement of the Government of the People's Republic of China on China's Territorial Sovereignty and Maritime Rights and Interests in the South China Sea, available at http:// www.fmprc.gov.cn/nanhai/eng/snhwtlcwj_1/t1379493.htm, last visited on December 9, 2018. 
and continental shelf, but also those over which China enjoys historic rights according to general international law. Article 2 of the 1982 Marine Environment Protection Law (amended in 1999) stipulates that, its scope of application is "the internal waters, territorial seas, contiguous zones, exclusive economic zones and continental shelves of the People's Republic of China and all other sea areas under the jurisdiction of the People's Republic of China". Apparently, "all other sea areas under the jurisdiction of the People's Republic of China" here obviously include the sea areas over which China is entitled with historic rights based on general international law. Afterwards, the same provision on the scope of marine areas within China's jurisdiction is also contained in Article 2 of the 1986 Fisheries Law (amended in 200o) ) $^{38}$ and Article 2 of the Provisions of the Supreme People's Court on Several Issues Concerning the Trial of the Relevant Cases Occurring in Sea Areas under the Jurisdiction of China, which was issued by the Supreme People's Court in 2016. ${ }^{39}$

On the other hand, China has consistently maintained that reasonable consideration should be given to the interests of coastal States, other States and international community as a whole. The UNCLOS mainly establishes the basic legal regimes for nine categories of maritime space. Among them, seven are under national jurisdiction, that is, internal waters, territorial seas, contiguous zones, straits used for international navigation, archipelagic waters, EEZ, and continental shelf. The other two, high seas and the Area, are beyond national jurisdiction. Such regime mirrors that coastal States' sovereignty, sovereign rights and jurisdiction should be balanced with other States' rights and freedom of navigation, overflight and the laying of submarine cables and pipelines. It also indicates the balanced interests between different State and international community as a whole. When exercising rights and performing duties, States should safeguard the interests of coastal States, while having due regard to the interests of other States and of the international community as a whole.

\subsection{Maritime Activities}

China considers that the basic rules of maritime activities contained in the UNCLOS should be strictly followed by each State. The UNCLOS establishes the basic legal regime for each State's conduct of activities including navigation, overflight, marine scientific research, environmental protection,

38 Available athttp://www.moa.gov.cn/gk/zcfg/fl/200601/t2006o120_539493.htm, last visited on December 9, 2018.

39 Available at http://www.court.gov.cn/fabu-xiangqing-24261.html, last visited on December 9, 2018. 
conservation and utilization of resources, the construction of artificial islands, and the laying of submarine cables. China insists that, each State should safeguard coastal States' sovereign rights and jurisdiction over its marine areas, as well as the right of navigation, overflight and the laying of submarine cables enjoyed by other States within the marine areas under coastal States' jurisdiction. Meanwhile, the rights enjoyed by each State in the high seas and the Area should also be protected and respected. When carrying out maritime activities, including military activities at seas, each State should strictly adhere to various UNCLOS rules, including stipulations regarding for peaceful purposes, international cooperation, protection and preservation of marine environment, mutual due regard, good faith and prohibition of abuse of rights, the adherence to domestic law of coastal States and the rule of residual rights, so as to safeguard a fair and reasonable marine order.

\subsection{Maritime Jurisdiction}

China insists exercising jurisdictions over maritime areas, matters, vessels or conducts in accordance with the stipulations of the UNCLOS. As a State Party to the UNCLOS, China claims territorial sovereignty over its internal water and the territorial sea, including exercising legislative jurisdiction and enforcement jurisdictions over relevant matters.

Within the contiguous zone, China insists the rights to exercise the law enforcement jurisdiction necessary to prevent or punish infringement of its customs, fiscal, immigration, sanitary and security laws and regulations within its territory or territorial sea. Pursuant to Article 303(2) of the Convention, the coastal State has the right to exercise enforcement jurisdiction over the removal of objects of an archaeological and historical nature from the sea-bed in the contiguous zone.

China also holds that the coastal State enjoys the sovereign rights in the EEZ over the natural resources and economic exploitation and exploration, and has jurisdiction with regard to the establishment and use of artificial islands, installations and structures, marine scientific research and the protection and preservation of the marine environment. The coastal State also has the right to take necessary measures against the acts of the foreign vessels or the crew in violation of its sovereign rights over the natural resources in the EEZ, including boarding, inspection, arrest and judicial proceedings (Articles 56 and 73 of the Convention). In addition, the coastal State can take necessary law enforcement measures or initiate judicial proceedings against the foreign acts in violation of the prevention, reduction and control of vessel-induced pollution in the EEZ (Article 220 of the Convention). 
China maintains that the coastal State enjoys sovereign rights and the relevant jurisdiction over the continental shelf in its exploration and exploitation of its natural resources. The natural resources here consist of the mineral and other non-living resources of the seabed and subsoil, together with living organisms belonging to sedentary species. According to Article 79 of the Convention, the coastal State enjoys jurisdiction over cables and pipelines constructed or used in connection with the exploration of its continental shelf or exploitation of its resources or the operations of artificial islands, installations and structures under its jurisdiction. According to Article 80 of the Convention, the coastal State enjoys exclusive jurisdiction over artificial islands, installations and structures on the continental shelf. According to Article 81 of the Convention, the coastal State has the exclusive right to authorize and regulate drilling on the continental shelf. According to Article 246, the coastal State has the jurisdiction over the marine scientific research on its continental shelf.

Regarding marine environmental protection, China is of the view that the coastal State has the legislative jurisdiction under Section 5 in Part XII of the UNCLOS, to prevent, reduce and control pollution from land-based sources, from seabed activities subject to national jurisdiction, by dumping and from vessels. Article 220 also provides that the coastal State may exercise enforcement jurisdiction over vessels which cause pollution within its territorial sea or the EEz.

In addition, China holds that the flag State has the right to exercise exclusive jurisdiction over the vessels flying its flag on the high seas or in the EEZ (Article 92 of the Convention). China also holds that State Parties should exercise judicial jurisdictions over, the right to visit and the hot pursuit right against the unlawful acts on the high seas or in the EEz including the piracy, transport of slaves, illicit traffic in narcotic drugs or psychotropic substances, and unauthorized broadcasting (Articles 99, 100, 108, 109, 110 and 111).

\subsection{Maritime Delimitation}

China has consistently insisted that, the delimitation of the EEZ and continental shelf between China and the States with opposite or adjacent coasts shall be effected by agreement on the basis of international law in accordance with the equitable principle. Meanwhile, according to the provisions and spirit of the UNCLOS, the delimitation of continental shelf should also follow the natural prolongation principle. China claims, when dealing with the delimitation of the EEZ and continental shelf in the East China Sea, the Yellow Sea and the South China Sea, the solutions should be reached through negotiations 
between countries directly concerned based on the equitable principle and the natural prolongation principle.

Concerning the establishment of the outer limits of the continental shelf beyond 2oonm, China supports the Commission to strictly adhere to the rule that "no consideration should be made when disputes exist", as provided in Annex I to its Rules of Procedure to deal with the submissions related to an area under dispute. This means that, in case where a land or maritime dispute exists, the Commission shall not consider and qualify a submission made by any States party concerned in the dispute, but the Commission may consider one or more submissions in the area under dispute with prior consent given by all States parties to the dispute. ${ }^{40}$

\subsection{The Means of Dispute Settlement}

China holds the consistent position that, each State should settle disputes peacefully through negotiations and consultations on the basis of respecting historical facts and international law. Concerning the disputes related to territorial sovereignty and maritime entitlements, China always insists that the solution should be reached through negotiation and consultation between the States directly concerned in accordance with international law. Any thirdparty dispute settlement mechanism is not acceptable to China. Since its founding in 1949, the People's Republic of China has successfully resolved land boundary disputes with twelve out of its fourteen neighbours except India and Bhutan. China and Viet Nam also have delimited their maritime boundary in Beibu Bay through negotiations and consultations. In addition, China and the Republic of Korea have commenced the negotiation on maritime delimitation in the Yellow Sea.

China is convinced that the determination of maritime entitlements is premised on the determined territorial sovereignty of maritime features. China considers that when dealing with the disputes relating to maritime entitlements of the maritime features, the territorial sovereignty of the relevant features should be decided upon first, after which the maritime entitlements could be decided in accordance with the UNCLOS.

China insists that, determination of means of dispute settlement between any two or more States, including resorting to international judicial and arbitral bodies, should be based on the consent of the Parties concerned. The UNCLOS provides a two-layer dispute settlement regime, according to which

40 CLCS/40/Rev.1, Rules of Procedure of the Commission on the Limits of the Continental Shelf, available at http://www.un.org/Depts/los/clcs_new/commission_documents .htm\#Rules of Procedure, last visited on December 9, 2018. 
the means of the Parties' own choice prevails when the compulsory procedures play a supplementary role. The priority of the Parties' own choice should be respected and protected.

As a Contracting Party of the UnClos, China only accepts the compulsory procedures when certain conditions are met. First, the disputes should be limited to those concerning interpretation and application of the UNCLOS, excluding the disputes concerning territorial sovereignty, historic rights and outlying archipelagos of a continental State in general international law. A second precondition is the exhaustion of dispute settlement procedures of the Parties' own choice, not including the disputes which China and other States have agreed to settle by means of their own choice. When the views have not been exchanged on the means to settle the disputes, the compulsory procedures should not be resorted to, either. Third, restricted by Article 297 of the UNCLOS, the disputes concerning the right to carry out marine scientific research and fisheries rights in the coastal States' EEZ and continental shelf should be excluded. Fourth, restricted by the exceptions provided in Article 298 of the UNCLOS, disputes referred to in China's 2006 statement accordingly should be excluded, including the disputes concerning maritime delimitation, historic bays and titles, military and enforcement activities, and those in respect of which the UN Security Council is exercising the functions assigned to it by the UN Charter.

China holds that, the third-party compulsory dispute settlement procedures contained in the UNCLOS are not applicable to the issue concerning the territorial sovereignty of Nanhai Zhudao and maritime delimitation. Such issues should be properly settled through negotiation and consultation between the disputant States. Before the final settlement, we may shelve disputes and carry out joint development.

\subsection{The Development of Legal Regime}

China suggests that the UNCLOS should demonstrate both its stability and adaptability. As the foundation of modern legal order of the oceans and seas, the UNCLOS receives universal application across the world. The regimes established under the UNCLOS are supposed to be relatively stable. Meanwhile, uncertainties and gaps still exist in the UNCLOS. Moreover, new challenges are brought about by the improved technology and diverse maritime activities of mankind. The regimes and rules in the Convention should keep abreast with the times, which can be achieved through State practice, renewed interpretation, and development of new rules. As stated above, the Chinese government attaches great importance to, actively participates and plays a constructive role in the negotiation of the international instrument on $\mathrm{BBNJ}$ 
and has submitted China's views and proposals. ${ }^{41}$ China insists that the new instrument should be consistent with the object and purpose of the UNCLOS. It should not deviate from the principles and spirit of the UNCLOS or undermine its existing framework. The freedoms and rights in respect of navigation, scientific research and fishing enjoyed by States under the UNCLOS should not be derogated. The new international instrument should contravene neither current international law, nor existing global, regional or sectoral marine mechanisms. Meanwhile, the new international instrument should facilitate cooperation and coordination with existing relevant international bodies and avoid overlap or conflict of functions. Relevant institutional arrangements of the new international instrument should have sound legal basis and solid scientific basis, while maintain a reasonable balance between the conservation and sustainable use in BвNJ. The new international instrument should accommodate the interests and concerns of all sides. It should also be based on interests and needs of the international community as a whole and the absolute majority of States, and special attention should be paid to interests of the developing States.

With respect to the marine genetic resources (MGRs), the Chinese government asserts that the institutional arrangement shall promote marine scientific research and innovation, and facilitate the access to the genetic resources, without undermining the freedom of marine scientific research and the regime of intellectual property rights (IPRs). China is of the view that the derivatives should not be included in scope of the MGRs. The fish as the carrier of the MGRs and the fish as commodity should be differentiated, the latter should be regulated by the 1995 UNFSA and relevant regional fisheries agreements. The in situ access to the MGRs in the Area or on the high seas falls within the scope of marine scientific research and the free access regime shall thus be applied. China also holds that the monetary benefit-sharing mechanism should not be applied before the large scale commercialized exploitation.

Regarding the marine protected areas (MPAS), the Chinese government proposes to establish the Conference of Parties (COP) and its subordinate bodies to consider, manage and monitor the MPAs, without undermining the existing global, regional and sectoral mechanisms. The objects of protection of the MPAs should be marine biodiversity. The MPAs should be established based on

41 Written Submission of the Government of the People's Republic of China on Elements of a Draft Text of an International Legally Binding Instrument under the United Nations Convention on the Law of the Sea on the Conservation and Sustainable Use of Marine Biological Diversity of Areas Beyond National Jurisdiction (As revised on April 20, 2017), available at http://www.un.org/depts/los/biodiversity/prepcom_files/streamlined/China .pdf, last visited on December 9, 2018. 
the best available scientific evidence. The areas should be identified, on a caseby-case basis, with standards of the biological and ecological factors, as well as the social and economic factors. The MPA proposals should be proposed by the States Parties and be considered, decided and monitored by the cop.

Regarding the environmental impact assessments (EIAS), the Chinese government maintains that, in accordance with Articles 204 to 206 of the Convention, the EIAs should be led by States and decided by States, including the initiation, decision-making and the implementation of the EIAs. The threshold of the EIAs should be that while States have "reasonable ground for believing" that such activities "may causes substantial pollution of or significant and harmful changes to the marine environment". The strategic environmental assessments are not supported to include in the new instrument. The Chinese government objects to include the so-called "adjacency principle" and insists of applying the "due regard" rules to address the concern of the adjacent coastal States over the activities in the areas beyond the national jurisdiction. Furthermore, the EIAs should follow certain statuary procedures.

On capacity building and transfer of marine technology, the Chinese government maintains that the interests and necessities of the developing States should be fully taken into account. The institutional arrangement of the capacity building and transfer of marine technology should be based on the principles of equality and voluntariness, win-win cooperation, the protection of IPRS and the preferential treatment to developing countries. States are encouraged to carry out international cooperation with the developing States. China supports to establish an open and transparent clearinghouse mechanism, which should be shared by all stakeholders. States Parties can submit the reports to the COP on the implementation of the capacity building and transfer of marine technology. The COP will consider the reports and make recommendations accordingly.

Meanwhile, the Chinese government has been actively participating in the work of the formulation of the exploitation regulations of the deep-sea mineral resources and has submitted China's comments and proposals. ${ }^{42}$ The Chinese government insists that the Exploitation Regulations should comply with the provisions and spirit of the Convention and the 1994 Implementing Agreement in a comprehensive and complete manner. The Exploitation Regulations should strike a reasonable balance between the benefits of mankind and

42 Comments by the Government of the People's Republic of China on the Draft Regulations on Exploitation of Mineral Resources in the Area (20 December 2017), available at http:// www.isa.org.jm/files/documents/EN/Regs/2017/List-1.pdf, last revisited on December 9, 2018. 
the interests of sponsoring States and Contractors that they have sponsored. Taking resources exploitation and environmental protection into consideration, the Exploitation Regulations should be oriented towards encouraging and promoting the exploitation of resources, while ensuring that marine environment is protected from substantial pollution or severe and harmful impacts in accordance with the law. The Exploitation Regulations should clearly and explicitly define the rights, obligations and responsibilities of various parties including Contractors, sponsoring States and the Authority. It should accommodate current human activities in the Area and the corresponding level of knowledge, and establish the corresponding regimes, rules and standards on the basis of objective facts and scientific evidence. It should also be compatible with the three explorations regulations and be consonant with the relevant rules of the ввNJ. The dispute settlement mechanisms set by the Exploitation Regulations should allow and encourage the parties to settle their disputes primarily through negotiation and consultation, based on compliance with the relevant provisions of the Convention and the Implementing Agreement.

The Chinese government maintains that the Exploitation Regulations shall should incorporate an equitable and reasonable payment mechanism and adopt the regime of royalty or a combination of royalty and profit-sharing as provided for in the 1994 Implementing Agreement. The regime of benefitsharing and the enterprise should be included in the regulations. It is also proposed that the Exploitation Regulations should address the compatibility between its environmental impact assessments regime and the regional environmental management plans, and take into account the differences of various mineral resources in the seabed and provide respective stipulations.

Vast is the ocean, vaster is the sky, and still the vastest is the mind of mankind. All of you present today, as practitioners and researchers of international law, have played significant roles in promoting the effective implementation, correct interpretation and wide dissemination of international law of the sea centered with the UNCLOS, and shoulder major responsibility in this regard. Encountered with new opportunities and challenges, China would like to work with you all to abide by the principles and spirits of the Convention, and make greater efforts in and contribution to safeguarding a fair and reasonable international marine order, as well as building a harmonious global ocean with lasting peace and common prosperity. 